\title{
Intellectual Property and Maps: Legal Protections for Cartographic Works from the Nineteenth to the Twenty-First Century
}

\author{
Jack Swab \\ University of Kentucky, jswab@uky.edu
}

Keywords: copyright, intellectual property, map studies, legal studies, cartographic production, history of cartography, fire insurance maps

\begin{abstract}
:
Copyright and intellectual property law is an essential aspect of both historical and contemporary mapping processes but has been little studied within the field. This paper examines the importance of intellectual property to the larger enterprise of cartography, seeking to contextualize and historicize the process through which copyright became the dominate way to protect one's map and the data within it. Using fire insurance maps in the United States as a case study, this paper traces laws and their pronounced impacts on the process of cartography more broadly.
\end{abstract}

Fire insurance maps represent a unique case study from which to examine this topic due to the industry's competitive nature. Early fire insurance map producers frequently clashed with each other due to the high cost of production and the nearly identical nature of their products. One court case, which pitted two early fire insurance map companies (the Perris \& Brown Map Company of New York City and the Hexamer Map Company of Philadelphia) against each other, resulted in an 1879 United States Supreme Court case that redefined the rules around map symbolization and cartographic intellectual property.

Yet it was only with another United States Supreme Court decision in 1884, that regular copyrighting of fire insurance maps began. The practice of copyrighting maps emerged in the twentieth century as a standard practice in companies, yet the effectiveness and practicality of these measures led to uneven enforcement and legal protections as the nature of maps changed. Because of this contested history there are significant legal ramifications for cartography today, impacting all facets of map use, whether that be historical maps in a map library or data sharing agreements for digital maps. The paper concludes by looking at an ongoing federal case involving fire insurance maps, which at the time of writing, remains unresolved. Through this analysis of copyright and fire insurance maps, this paper asserts that copyright and intellectual property disputes are an essential area in the history of cartography that deserve more attention. 